\title{
Can Bulk and Nanosized Titanium Dioxide Particles Improve Seed Germination Features of Wheatgrass (Agropyron desertorum)
}

\author{
Reyhaneh AZIMI', Hassan FEIZI ${ }^{2 *}$, Mohammad KHAJEH HOSSEINI ${ }^{3}$ \\ ${ }^{1}$ Ferdowsi University of Mashhad, Faculty of Natural Resources and Environment, Range \\ Management Department, Iran; reyhaneazimi90@yahoo.com \\ ${ }^{2}$ University of Torbat-e-Heydarieh, Torbat Heydarieh, Iran; hasanfeizi51@yahoo.com ( ${ }^{*}$ corresponding author) \\ ${ }^{3}$ Ferdowsi University of Mashbad, Faculty of Agriculture, Department of Crop Science,Mashhad, Iran; saleh@ferdowsi.um.ac.ir
}

\begin{abstract}
The goal of this study was to evaluate concentrations of nanosized $\mathrm{TiO}_{2}$ at $0,5,20,40,60$ and $80 \mathrm{mg} \mathrm{L}^{-1}$ with bulk $\mathrm{TiO}_{2}$ for possible stimulatory effects on wheatgrass seed germination and early growth stage. After 14 days of seed incubation, germination percentage improved by $9 \%$ following exposure to 5 ppm nanosized $\mathrm{TiO}_{2}$ treatment comparing to control. Similar positive effects occurred in terms of germination value and mean daily germination. Application of bulk $\mathrm{TiO}_{2}$ particles in $80 \mathrm{ppm}$ concentration greatly decreased the majority of studied traits. Therefore phytotoxicity effect observed on wheatgrass seedling by application of bulk TiO 2 particles in 80 ppm concentration. Exposure of wheatgrass seeds to 5 ppm nanosized $\mathrm{TiO}_{2}$ and bulk and nanosized $\mathrm{TiO}_{2}$ at 60 ppm obtained the lowest mean germination time but higher concentrations did not improve mean germination time. In general, there was a positive response by wheatgrass seed to some concentrations of nanosized $\mathrm{TiO}_{2}$. Usage of nanoparicles in order to improve germination and establishment of range plant in adverse environments similar to rangeland could be possible.
\end{abstract}

Keywords: mean germination time, nanosized $\mathrm{TiO}_{2}$, seed germination

\section{Introduction}

Nowadays, various researchers have studied the effects of nanomaterials on plant germination and growth with the objective to promote its use for agricultural applications (Khot et al., 2012). Nanosized $\mathrm{TiO}_{2}$ is a frequently used nanoparticle, consequently there has been an exponential increase in data collection on the effects of $\mathrm{TiO}_{2}$ nanoparticles on different species but there is much less information on the effects of nanoparticles on plants compared to animals. Studies the effects of $\mathrm{TiO}_{2}$ nanoparticles on plants provide information about the positive and stimulating effects as well as any negative impact (Klancnik et al., 2011). Despite the low availability of Ti element to plants, its beneficial effects on plants have already been proved. In oats (Avena sativa), Ti uptake as a nutrient solution by roots was more effective than spraying it on the leaves, benefiting various plant physiological parameters such as biomass yield, chlorophyll content, and growth (Kuzel et al., 2003). Kiss et al. (1985) and Daood et al. (1998) also showed that Ti could activate photosynthesis, probably by changing the redox state of specific regulatory proteins and eliciting an alteration in enzyme activity, the most important enzyme being fructose-1,6-bisphosphatase (F-1,6BP), which participates in the Calvin cycle, gluconeogenic, and oxidative pentose phosphate pathways of carbohydrate metabolism which are assumed to be associated with $\mathrm{Ti}$.

Haghighi et al. (2012) demonstrated that $1 \mathrm{mg} \mathrm{L}^{-1} \mathrm{Ti}$ can almost fully compensate the fresh and dry weight of shoots and roots, flowering time, number of flowers, chlorophyll content, and photosynthetic capacity of tomato when nitrogen is reduced by $50 \%$. This has very practical applications for tomato hydroponic culture by maximizing macronutrient and micronutrient absorption while lowering $\mathrm{N}$ concentration by half, thus making the system more cost-effective.

In arid and semiarid regions with low and unreliable rainfall, germinating seeds are often experience different durations of drought stress. Seed germination of various plant species may respond differently to dry conditions (Wilson, 1973).

Crested wheatgrass (Agropyron desertorum) is a perennial bunchgrass and one of the important species of the Poacea family. It is widely used for rangeland rehabilitation on light-textured soils of both shrub lands and grasslands where the rainfall is low (Bassiri et al., 1988). Under rangeland conditions, seeds are often exposed to high and low temperatures and severe drought. Hence, choosing suitable techniques for increase seed tolerance to adverse conditions would serve to increase the probability of success (Wilson, 1973). 
326

The key reason for the increased growth rate by $\mathrm{TiO}$ nanoparticles could have been the photo-sterilization and photo-generation of "active oxygen like superoxide and hydroxide anions" by nano $\mathrm{TiO}_{2}$ that can increase the seed stress resistance and promote capsule penetration for intake of water and oxygen needed for fast germination. (Khot et al., 2012). The key to increased seed germination rate is the penetration of nanomaterials into the seed. Khodakovskaya et al. (2009) reported that multi wall carbon nanotubes can penetrate into the tomato seeds and increase the germination rate by increasing water uptake. The Multi wall carbon nanotubes (MWCNT) increased the seed germination, up to $90 \%$ (compared to $71 \%$ in control) in 20 days, and the plant biomass.

Foltete et al. (2011) stated that altered $\mathrm{TiO}_{2}$ nanocomposites and phytochelatins levels showed no modify on plant growth, photosystem II maximum quantum yield, genotoxicity (micronucleus test) compared to controls (Foltete et al., 2011). Zheng et al. (2005) confirmed that nanosized $\mathrm{TiO}_{2}$ helped water absorption in spinach seeds and as result enhanced seed germination. Lu et al. (2002) shown that a combination of nanosized $\mathrm{SiO}_{2}$ and $\mathrm{TiO}_{2}$ could increase nitrate reductase enzyme in soybean $\left(G_{l y}{ }^{2}\right.$ cine max) and its abilities of absorbing and utilizing water and fertilizer, promoting antioxidant system, and finally accelerate its germination and growth. Also, the positive effects of $\mathrm{TiO}_{2}$ could be probably due to the antimicrobial properties of engineered nanoparticles, which can enhance resistance of plants to stress (Navarro et al., 2008).

Some reports have demonstrated that nanoparticles can induce phytotoxicity and have a negative impact on seed germination and growth while using unique properties of some nanoparticles it will possible to improve seed germination and crop performance. This use of the potentially positive effects of nanoparticles may be a helpful approach to decrease consumption of chemical agents in agriculture that would help to lower environmental pollution. Results of our earlier work demonstrated that using nanosized $\mathrm{TiO}_{2}$ in low concentration ( 2 and $10 \mathrm{ppm}$ ) could encourage seed germination of wheat in comparison
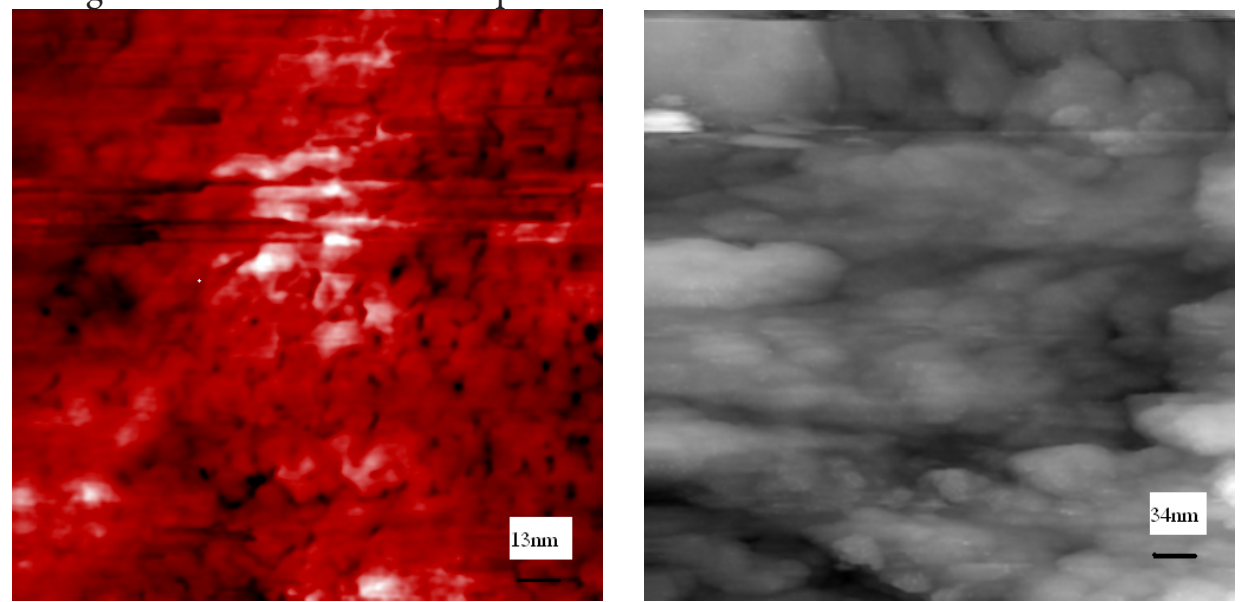

Fig. 1. Images of nanosized $\mathrm{TiO}_{2}$ by Scanning Tunneling Microscope (STM) to bulk $\mathrm{TiO}_{2}$ and untreated control groups, but in high concentrations (100 and $500 \mathrm{ppm}$ ) it indicated an inhibitory or no effect on wheat seed (Feizi et al., 2012). However weak seed germination is a common occurrence in some rangeland plants and there are limited studies on the effects of nanoparticles on rangeland plants particularly wheatgrass. This study was consequently performed to explore possible phytotoxicity and/or stimulatory effects of nanosized $\mathrm{TiO}_{2}$ concentrations compared to the bulk $\mathrm{TiO}_{2}$ particles on wheatgrass seed and seedling growth.

\section{Materials and methods}

\section{Description of materials}

Wheatgrass (Agropyron desertorum) seeds were taken from Karnakh Research Station, Natural Resources Organization of Mashhad. Nanosized $\mathrm{TiO}_{2}$ powder was AEROXIDE $\mathrm{TiO}_{2}$ P25, supplied by Degussa $\mathrm{GmbH}$ Company. Specific surface area of nanosized $\mathrm{TiO}_{2}$ was 50 $\mathrm{m}^{2} \mathrm{~g}^{-1}$, average primary particle size was $21 \mathrm{~nm}$ and purity was $>99.5 \%$. The size of $\mathrm{TiO}_{2}$ nanoparticles (Fig. 1) was determined through Scanning Tunneling Microscope (STM) in Central Laboratory of Ferdowsi University of Mashhad.

Analysis of $\mathrm{x}$-ray diffraction (XRD) of nanoparticles $\mathrm{TiO}_{2}$ was shown in Fig. 2. XRD measurement showed that the $\mathrm{TiO}_{2}$ nanoparticles used in the study were made by $80 \%$ anatase and $20 \%$ rutile. Analysis of particles in Xray diffraction indicates Tetragonal particles and the crystalline nature of $\mathrm{TiO}_{2}$ particles.

Bulk $\mathrm{TiO}_{2}$ particles were supplied by AppliChem GmbH Company, they had 99\% purity and particle size was measured by Scanning Electron Microscope (SEM) in Central Laboratory of Ferdowsi University of Mashhad (Fig. 3). XRD measurement showed that the bulk $\mathrm{TiO}_{2}$ particles used in the research were made by $100 \%$ anatase. Analysis of particles in X-ray diffraction indicated particles with tetragonal shape and the bulk $\mathrm{TiO}_{2}$ particles had a crystalline nature (Fig. 4). 


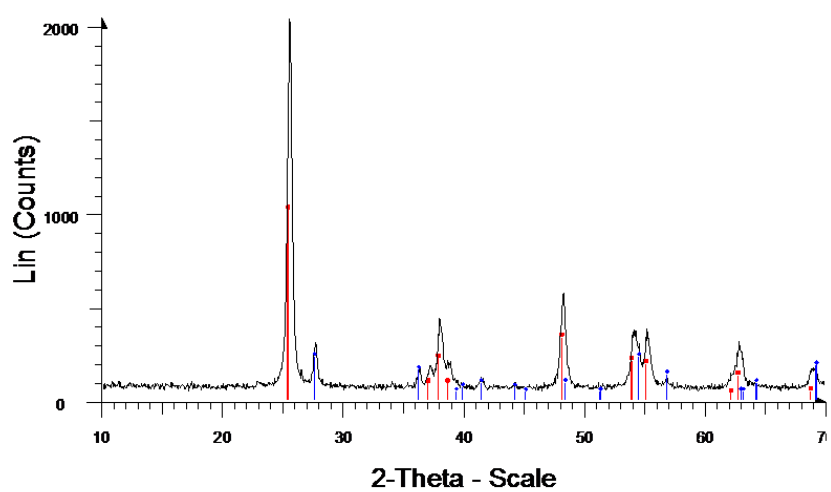

Fig. 2. X-ray diffraction (XRD) pattern of nano $\mathrm{TiO}_{2}$ particles

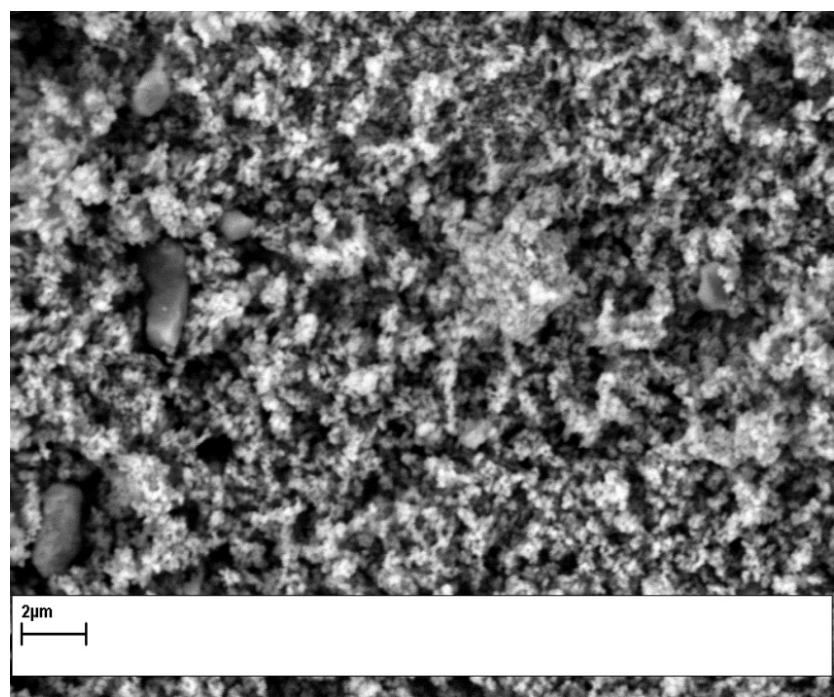

Fig. 3. Image of bulk $\mathrm{TiO}_{2}$ particles by Scanning Electron $\mathrm{Mi}$ croscope (SEM)

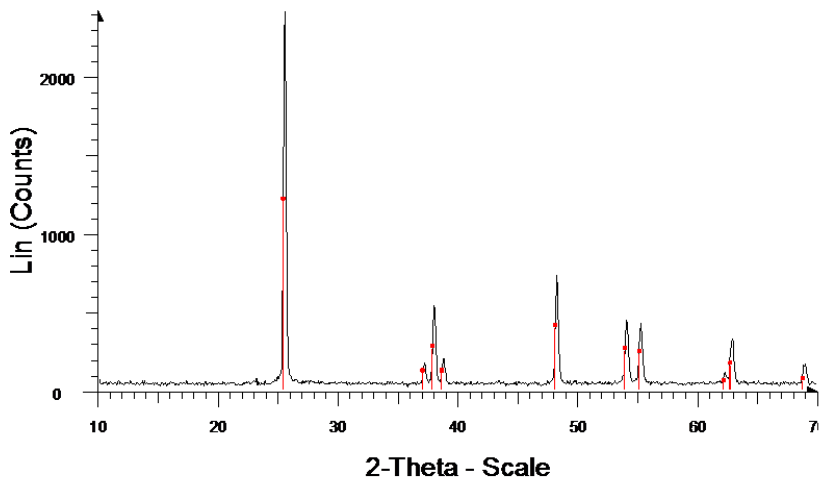

Fig. 4. X-ray diffraction (XRD) pattern of bulk $\mathrm{TiO}_{2}$ particles

Seed culture and exposure

Experiment was made to evaluate the effect of different concentrations of bulk and nanosized $\mathrm{TiO}_{2}$ on wheatgrass seed germination in a completely randomized design with four replications. The treatments in the experiment were five concentrations $(5,20,40,60$ and $80 \mathrm{ppm})$ of bulk and five concentrations $(5,20,40,60$ and $80 \mathrm{ppm})$ of nanosized $\mathrm{TiO}_{2}$ and an untreated control (without any $\mathrm{TiO}_{2}$ types). Prechilling treatment on seeds exert at $4^{\circ} \mathrm{C}$ for 7 days before beginning of ger- mination test (ISTA, 2009). The Experiment was performed in a germinator with an average temperature of $25 / 15 \pm 1^{\circ} \mathrm{C}$ for 16/8 hours (day/night) at the College of Natural Resources, Ferdowsi University of Mashhad, Iran in 2012.

Seeds of similar size were randomly selected and sterilized using $\mathrm{NaClO}$ (5\%) for 3 minutes and then carefully washed with distilled water three times. In order to obtain properly dispersed and stable $\mathrm{TiO}_{2}$ suspensions of each concentration, an ultra-sonication treatment was applied to bulk and nanoparticles $\mathrm{TiO}_{2}$ powders dispersed in water for 15 minutes. The seeds were placed on paper in four groups of 25 seeds in Petri dishes, and after that $2 \mathrm{ml}$ of each concentration treatments was added. For the control, only distilled water was added to the Petri dishes. Germination tests were performed according to the rule issued by the International Seed Testing Association (ISTA, 2009). All concentrations of $\mathrm{TiO}_{2}$ and the control were tested at the same time to make sure uniform conditions of light and temperature across all tests. Number of germinated seeds was noted daily during 14 days. Seeds were considered germinated when the radicle showed at least $2 \mathrm{~mm}$ in length (ISTA, 2009). Mean germination time was calculated based on Matthews and Khajeh-Hosseini (2007) (Eq. 1):

$$
M G T=\frac{\sum F \times X}{\sum F}
$$

Where $\mathrm{F}$ is the number of seeds newly germinated at the time of $\mathrm{X}$, and $\mathrm{X}$ is the number of days from sowing.

Germination rate was determined based on Maguire (1982) (Eq. 2):

Germination rate $=(a / 1)+(b-a / 2)+(c-b / 3)+\ldots . .+(n-$ $\mathrm{n}-1 / \mathrm{N})$

Eq. 2

Where $\mathrm{a}, \mathrm{b}, \mathrm{c}, \ldots, \mathrm{n}$ are numbers of germinated seeds after $1,2,3, \ldots, \mathrm{N}$ days from the start of imbibition.

Seedling vigors were computed based on Vashisth and Nagarajan (2010) (Eq. 3 and 4): (cm)

Vigor index I = Germination\% $\times$ Seedling length (g)

Vigor index II = Germination $\% \times$ Seedling weight$$
\text { Eq. } 4
$$

Evaluations of Mean Daily Germination (MDG), Pick Value (PV) and Germination Value (GV) were calculated by the following equations (Hartmann et al., 1990):

MDG = Germination\% / total experiment days Eq. 5

$\mathrm{PV}=$ Maximum germinated seed number at one day / day number

$\mathrm{GV}=\mathrm{PV} \times \mathrm{MDG}$

Eq. 6

Eq. 7

\section{Data analysis}

Analysis of variance (ANOVA) was performed between treatment samples in a completely randomized design in four replications. Records were analyzed using MSTAT-C computer software. Significant levels of difference for all studied traits were calculated and means were compared by the multiple ranges Duncan test at $5 \%$ level. 
328

\section{Results and discussion}

Results demonstrated that treatments in this experiment had significant effects on most of studied traits. Employment of $\mathrm{TiO}_{2}$ nanoparticle with 5 ppm enhanced wheatgrass seed germination, while seed germination percentages decreased from exposure to $80 \mathrm{ppm}$ concentrations of bulk and nano $\mathrm{TiO}_{2}$ particles compared to the control group (Tab. 1). It seems that the highest concentration of bulk and nano $\mathrm{TiO}_{2}$ particles had phytotoxity effect on seed germination.

Wheatgrass seeds exposed to 5 ppm $\mathrm{TiO}_{2}$ nanoparticles exhibited improvements in seed germination percentage by $9 \%$ compared to the control. The main reason for this increased growth rate could have been the photosterilization and photo-generation of "active oxygen like superoxide and hydroxide anions" by nano- $\mathrm{TiO}_{2}$ that enhanced seed stress resistance and encouraged capsule penetration for intakes of water and oxygen needed for quick germination (Khot et al., 2012). An earlier study was done (Feizi et al., 2012) demonstrating that although the highest germination percentage (98\%) was in both 2 ppm bulk and nanosized $\mathrm{TiO}_{2}$ concentrations, the two treatments had no significant effect on the seed germination percentage. Zheng et al. (2005) reported that nanosized $\mathrm{TiO}_{2}$ contributed to water absorption by spinach seeds and as result accelerated seed germination. Clément et al. (2012) reported that soaking of flax seeds in the suspensions of $\mathrm{TiO}_{2}$ nanoparticles at $100 \mathrm{mg} \mathrm{L}^{-1}$ concentration had positive effects on seed germination and root growth. These positive effects could be due to antimicrobial properties of anatase crystalline structure of $\mathrm{TiO}_{2}$ that increase plant resistance to stress (Clément et al., 2012).

Shoot, root and seedling elongation were significantly affected by bulk and nanosized $\mathrm{TiO}_{2}$ treatments. Application of bulk $\mathrm{TiO}_{2}$ at 5 ppm, nano $\mathrm{TiO}_{2}$ at $40 \mathrm{ppm}$ and bulk $\mathrm{TiO}_{2}$ at 60 ppm demonstrated the highest shoot and seedling length, but bulk $\mathrm{TiO}_{2}$ at $80 \mathrm{ppm}$ showed the lowest shoot and seedling length. Treatments had not significant effect on root length. Use of bulk $\mathrm{TiO}_{2}$ particles in $80 \mathrm{ppm}$ concentration greatly decreased shoot dry weight up to $42 \%$ compared to the control seeds while at the concentration of $80 \mathrm{ppm}$ nano $\mathrm{TiO}_{2}$ did not demonstrate such reduction in shoot biomass (Tab. 1). The greatest shoot biomass was found in 5 ppm bulk particles (10.4 mg) of titanium dioxide. The highest root biomass was achieved from concentrations of 5 ppm bulk- $-\mathrm{TiO}_{2}$ and $40 \mathrm{ppm}$ nano- $\mathrm{TiO}_{2}$ but an increased concentration of bulk particles of $80 \mathrm{ppm}$ significantly reduced root dry weight. It is probable that increasing the concentration of bulk- $\mathrm{TiO}_{2}$ induced aggregation of particles and resulted in clogging of root pores that interrupted water uptake by seeds. It seems that nano $\mathrm{TiO}_{2}$ could stimulate process of seed germination like water and oxygen uptake led to improve seed germination percentage but in later growth stages, seedling might respond as different. Lin and Xing (2007) confirmed the phytotoxicity of nano- $\mathrm{Al}$ and $\mathrm{Al}_{2} \mathrm{O}_{3}$ significantly affected root elongation of ryegrass and corn, respectively whereas, nano-Al facilitated root growth in radish and rape. Although root length and weight are not standardized in toxicity tests, they may be helpful to compare the toxicity effects after seeds exposure to nanoparticles since low values can be related to non-acute toxicological or stress effects (Barrena et al., 2009). In an experiment, Barrena et al. (2009) stated that it seems that in the case of Fe-nanoparticles treatment, the development of thicker roots was favored, whereas in the case of $\mathrm{Au}$, root growth was mainly due to elongation. The root growth in length but not in width might be an avoidance mechanism of the seed to a stress issue produced by the presence of some nanoparticles (Barrena et al., 2009).

A lot of germination-related occurrences (gene transcription and translation, respiration and energy metabolism, early reserve mobilization and DNA repair) could also happen during seed treatment (Varier et al., 2010), although often restricted due to reduced water supply

Tab. 1. Influence of bulk and nanosized $\mathrm{TiO}_{2}$ concentrations on seed germination, elongation and biomass of wheatgrass seedling

\begin{tabular}{cccccccc}
\hline $\begin{array}{c}\mathrm{TiO}_{2} \text { concentration } \\
(\mathrm{ppm})\end{array}$ & $\begin{array}{c}\text { Germination } \\
(\%)\end{array}$ & $\begin{array}{c}\text { Shoot length } \\
(\mathrm{cm})\end{array}$ & $\begin{array}{c}\text { Root length } \\
(\mathrm{cm})\end{array}$ & $\begin{array}{c}\text { Seedling } \\
\text { length } \\
(\mathrm{cm})\end{array}$ & $\begin{array}{c}\text { Shoot dry } \\
\text { weight } \\
(\mathrm{mg})\end{array}$ & $\begin{array}{c}\text { Root dry } \\
\text { weight } \\
(\mathrm{mg})\end{array}$ & $\begin{array}{c}\text { Seedling } \\
\text { weight } \\
(\mathrm{mg})\end{array}$ \\
\hline Control & $79 \mathrm{ab}$ & $7.51 \mathrm{abc}$ & $6.55 \mathrm{a}$ & $14.06 \mathrm{bc}$ & $9.47 \mathrm{ab}$ & $3.45 \mathrm{bc}$ & $12.92 \mathrm{abc}$ \\
\hline $5 \mathrm{bulk}$ & $83 \mathrm{ab}$ & $8.97 \mathrm{a}$ & $7.97 \mathrm{a}$ & $16.95 \mathrm{a}$ & $10.4 \mathrm{a}$ & $5.57 \mathrm{a}$ & $15.97 \mathrm{a}$ \\
\hline 5 nano & $86 \mathrm{a}$ & $7.56 \mathrm{abc}$ & $7.61 \mathrm{a}$ & $15.18 \mathrm{~b}$ & $6.9 \mathrm{bcd}$ & $4.52 \mathrm{ab}$ & $11.42 \mathrm{bcd}$ \\
$20 \mathrm{bulk}$ & $73 \mathrm{ab}$ & $7.24 \mathrm{abc}$ & $8.52 \mathrm{a}$ & $15.76 \mathrm{ab}$ & $7.02 \mathrm{bcd}$ & $4.47 \mathrm{ab}$ & $11.5 \mathrm{bcd}$ \\
20 nano & $74 \mathrm{ab}$ & $6.08 \mathrm{bc}$ & $7.96 \mathrm{a}$ & $14.05 \mathrm{bc}$ & $6.45 \mathrm{~cd}$ & $4.5 \mathrm{ab}$ & $10.95 \mathrm{~cd}$ \\
40 bulk & $76 \mathrm{ab}$ & $7.77 \mathrm{ab}$ & $7.63 \mathrm{a}$ & $15.45 \mathrm{ab}$ & $8.42 \mathrm{abc}$ & $4.37 \mathrm{ab}$ & $12.8 \mathrm{abc}$ \\
40 nano & $84 \mathrm{ab}$ & $8.63 \mathrm{a}$ & $8.51 \mathrm{a}$ & $17.14 \mathrm{a}$ & $8.95 \mathrm{abc}$ & $5.72 \mathrm{a}$ & $14.67 \mathrm{ab}$ \\
\hline 6 bulk & $84 \mathrm{ab}$ & $8.61 \mathrm{a}$ & $8.73 \mathrm{a}$ & $17.34 \mathrm{a}$ & $9.15 \mathrm{abc}$ & $4.57 \mathrm{ab}$ & $13.72 \mathrm{abc}$ \\
60 nano & $78 \mathrm{ab}$ & $7.65 \mathrm{abc}$ & $8.4 \mathrm{a}$ & $16.05 \mathrm{ab}$ & $8.42 \mathrm{abc}$ & $4.52 \mathrm{ab}$ & $12.95 \mathrm{abc}$ \\
\hline $80 \mathrm{bulk}$ & $58 \mathrm{c}$ & $5.78 \mathrm{c}$ & $6.72 \mathrm{a}$ & $12.51 \mathrm{c}$ & $5.47 \mathrm{~d}$ & $2.65 \mathrm{c}$ & $8.12 \mathrm{~d}$ \\
80 nano & $70 \mathrm{bc}$ & $7.50 \mathrm{abc}$ & $7.79 \mathrm{a}$ & $15.29 \mathrm{ab}$ & $9.1 \mathrm{abc}$ & $4.35 \mathrm{ab}$ & $13.45 \mathrm{abc}$ \\
\hline
\end{tabular}

${ }^{*}$ Means, in each column, followed by similar letter are not significantly different at the $5 \%$ probability level- using Duncan's Multiple Range Test 
compared to regular germination (Chen and Bradford, 2000; Li et al., 2005). The key to increased seed germination rate is the penetration of nanomaterial into the seed. Khodakovskaya et al. (2009) reported that multi wall carbon nanotubes can penetrate tomato seed and increase the germination rate by rising water uptake. That multi wall carbon nanotubes increased seed germination up to $90 \%$ (compared to $71 \%$ in control) in 20 days; it also increased plant biomass.

On the whole, lower mean germination time represents earlier germination. These results revealed that exposure of wheatgrass seeds to $5 \mathrm{ppm}$ nanosized $\mathrm{TiO}_{2}$ and bulk and nanosized $\mathrm{TiO}_{2}$ at $60 \mathrm{ppm}$ obtained the lowest mean germination time but higher concentrations did not improve mean germination time. Thus, use of nanosized $\mathrm{TiO}_{2}$ at 5 and $60 \mathrm{ppm}$ reduced mean germination time by 14 and $11 \%$ in comparison to the untreated control respectively, whereas 5 ppm concentration of bulk $\mathrm{TiO}_{2}$ did not contribute to a reduction of mean germination time in comparison with the control (Tab. 2). Zheng et al. (2005) stated that the significant effect of nanosized $\mathrm{TiO}_{2}$ on spinach germination in tests was probably because of small particle size, which allowed nanoparticles to penetrate the seed during the treatment period, exerting its enhancing functions during growth.

Exposure of wheatgrass seeds to high concentrations of nano $\mathrm{TiO}_{2}$ particles $(80 \mathrm{ppm})$ led to diminished germination rate (Tab. 2). The highest germination rate was found in $60 \mathrm{ppm}$ bulk $\mathrm{TiO}_{2}$ particles $\left(5.26\right.$ seed day $^{-1}$ ) and increasing concentration decreased the germination rate. $\mathrm{Bulk}-\mathrm{TiO}_{2}$ treatment at $80 \mathrm{ppm}$ showed the lowest germination rate (2.91 seed day ${ }^{-1}$ ) (Tab. 2). In most cases (Zheng et al., 2005; Feizi et al., 2012, 2013), using bulk $\mathrm{TiO}_{2}$ particles significantly decreased germination value of seeds while nanosized $\mathrm{TiO}_{2}$ had a positive effect on germination value. It is most probable that nanoparticles could penetrate into the seed coat and exert a helpful effect on the process of seed germination but bulk particles, having a larger size, cannot easily enter the same pathway, therefore may accumulate in the pores of a seed coat and clog up water and oxygen transition. Based on studies on nanoparticles effects on mechanism of seed germination it could have stated that the nanoparticles might help water absorption by the seeds (Zheng et al., 2005), increase nitrate reductase enzyme, increase seed abilities of absorbing and utilizing water and fertilizer, promote seed antioxidant system (Lu et al., 2002), reduced anti oxidant stress by reducing $\mathrm{H}_{2} \mathrm{O}_{2}$, superoxide radicals, and malonyldialdehyde content, and increasing some enzymes such as superoxide dismutase, ascorbate peroxidase, guaiacol peroxidase, and catalase activities (Lei et al., 2008) result in improve seed germination in some plant species. Foltete et al. (2011) examined altered $\mathrm{TiO}_{2}$ nanocomposites (ATN) in the liquid phase on Vicia faba, exposed to three nominal concentrations 5, 25 and $50 \mathrm{mg}$ ATN/L for $48 \mathrm{~h}$. They concluded plant growth, photosystem II maximum quantum yield, genotoxicity (micronucleus test) and phytochelatins levels showed no change compared to controls.

Exposure of seeds to nano and bulk $\mathrm{TiO}_{2}$ particles at $80 \mathrm{ppm}$ significantly diminished MDG compared to the untreated control. However, the pick value (PV) of wheatgrass seedlings was not affected by different concentrations of bulk and nanoparticles. Application of bulk- $\mathrm{TiO}_{2}$ at 80 ppm concentration had a negative effect on vigor index I and II (Tab. 2). It has been stated that the biological activity and biokinetics of nanoparticles depends on parameters such as size, shape, chemistry, crystallinity, surface properties (area, porosity, charge, surface modifications, coating), agglomeration state, biopersistence, and dose (Casals et al., 2008). Zheng et al. (2005) showed that the growth of spinach plants was greatly improved at concentrations of 250 - 4,000 ppm nano $\mathrm{TiO}_{2}$ than concentrations of bulk$\mathrm{TiO}_{2}$. Ghosh et al. (2010) observed adverse effect of $\mathrm{TiO}_{2}$ nanoparticles for another plant species, Nicotina tabacum. They reported that $\mathrm{TiO}$, nanoparticles induced DNA injure in $N$. tabacum simply at high concentration (319 mg $\left.\mathrm{L}^{-1}\right)$ of $\mathrm{TiO}_{2}$ nanoparticles.

Tab. 2. Influence of bulk and nanosized $\mathrm{TiO}_{2}$ concentrations on growth features of wheatgrass seedling

\begin{tabular}{cccccccc}
\hline $\begin{array}{c}\mathrm{TiO}_{2} \text { concentration } \\
(\mathrm{ppm})\end{array}$ & $\begin{array}{c}\text { MGT } \\
(\text { day })\end{array}$ & $\begin{array}{c}\text { Germination rate } \\
(\text { seed day })^{-1}\end{array}$ & $\begin{array}{c}\text { Germination } \\
\text { value }\end{array}$ & MDG & PV & $\begin{array}{c}\text { Vigour } \\
\text { index I }\end{array}$ & $\begin{array}{c}\text { Vigour } \\
\text { index II }\end{array}$ \\
\hline Control & $5.38 \mathrm{a}$ & $4.51 \mathrm{ab}$ & $13.83 \mathrm{ab}$ & $6.07 \mathrm{ab}$ & $2.26 \mathrm{a}$ & $1111 \mathrm{abcd}$ & $1016 \mathrm{abcd}$ \\
\hline $5 \mathrm{bulk}$ & $5.88 \mathrm{a}$ & $4.36 \mathrm{ab}$ & $14.36 \mathrm{ab}$ & $6.38 \mathrm{ab}$ & $2.24 \mathrm{a}$ & $1412 \mathrm{ab}$ & $1343 \mathrm{a}$ \\
5 nano & $4.64 \mathrm{~b}$ & $4.55 \mathrm{ab}$ & $18.86 \mathrm{a}$ & $6.61 \mathrm{a}$ & $2.80 \mathrm{a}$ & $1307 \mathrm{abc}$ & $978 \mathrm{bcd}$ \\
$20 \mathrm{bulk}$ & $5.84 \mathrm{a}$ & $4.00 \mathrm{~b}$ & $11.98 \mathrm{bc}$ & $5.61 \mathrm{ab}$ & $2.10 \mathrm{a}$ & $1161 \mathrm{abc}$ & $838 \mathrm{cde}$ \\
20 nano & $5.44 \mathrm{a}$ & $3.70 \mathrm{bc}$ & $12.99 \mathrm{bc}$ & $5.69 \mathrm{ab}$ & $2.27 \mathrm{a}$ & $1039 \mathrm{~cd}$ & $812 \mathrm{de}$ \\
$40 \mathrm{bulk}$ & $5.16 \mathrm{ab}$ & $3.97 \mathrm{~b}$ & $12.87 \mathrm{bc}$ & $5.84 \mathrm{ab}$ & $2.16 \mathrm{a}$ & $1186 \mathrm{abc}$ & $966 \mathrm{bcd}$ \\
40 nano & $5.09 \mathrm{ab}$ & $4.60 \mathrm{ab}$ & $16.12 \mathrm{ab}$ & $6.46 \mathrm{ab}$ & $2.47 \mathrm{a}$ & $1439 \mathrm{a}$ & $1227 \mathrm{ab}$ \\
\hline 6 bulk & $4.78 \mathrm{~b}$ & $5.26 \mathrm{a}$ & $15.10 \mathrm{ab}$ & $6.46 \mathrm{ab}$ & $2.34 \mathrm{a}$ & $1457 \mathrm{a}$ & $1158 \mathrm{abc}$ \\
60 nano & $4.77 \mathrm{~b}$ & $5.02 \mathrm{~b}$ & $13.52 \mathrm{bc}$ & $6.00 \mathrm{ab}$ & $2.25 \mathrm{a}$ & $1260 \mathrm{abc}$ & $1025 \mathrm{abcd}$ \\
\hline $80 \mathrm{bulk}$ & $5.42 \mathrm{a}$ & $2.91 \mathrm{c}$ & $8.63 \mathrm{c}$ & $4.46 \mathrm{c}$ & $1.81 \mathrm{a}$ & $773 \mathrm{~d}$ & $526 \mathrm{e}$ \\
80 nano & $5.35 \mathrm{a}$ & $3.95 \mathrm{~b}$ & $11.18 \mathrm{bc}$ & $5.38 \mathrm{bc}$ & $2.05 \mathrm{a}$ & $1070 \mathrm{bcd}$ & $950 \mathrm{bcd}$ \\
\hline
\end{tabular}

*Means, in each column, followed by similar letter are not significantly different at the $5 \%$ probability level- using Duncan's Multiple Range Test 
330

\section{Conclusions}

Nanotechnology is leading to the progress of a range of inexpensive applications for enhanced plant growth. Applications of nanomaterial can encourage earlier plant germination and improve plant production. To our knowledge, this work is the first publication related to the effects of bulk and nanosized $\mathrm{TiO}_{2}$ particles in wheatgrass (Agropyron desertorum). Usually seed germination and establishment of wheatgrass is difficult in detrimental conditions of natural rangeland. Using $\mathrm{TiO}_{2}$ nanoparticles at low dosage could promote wheatgrass seed germination percentage, while seed germination percentages decreased following exposure to high concentrations of bulk and nano $\mathrm{TiO}_{2}$ particles compared to the control group. Exposure of wheatgrass seeds to 5 and 60 ppm nanosized $\mathrm{TiO}_{2}$ obtained the lowest mean germination time but higher concentrations did not improve mean germination time. Low and intermediate concentrations of nanosized $\mathrm{TiO}_{2}$ improved seedling growth indices but higher concentration $(80 \mathrm{ppm})$ had an inhibitory effect on seed and seedling. Application of bulk $\mathrm{TiO}_{2}$ at $80 \mathrm{ppm}$ reduced some traits in the study such as germination rate, GMD, $\mathrm{GV}$ and vigor index compared to nanosized $\mathrm{TiO}_{2}$ and the control. Nanomaterial can improve plant germination in certain plants but can have adverse affects on others. In such cases, nanomaterial can be applied for pretreatment of rangeland seeds and then cultivate in the natural rangelands to promote germination and establishment of seedling. Nevertheless, on the basis of these results it is highly recommended that the influence of low dose nanomaterial be assessed in order to encourage seed germination and seedling growth of different range plant species. Although this study demonstrated the potential of nanomaterial for natural resources application, additional exploration and research is needed to elucidate and develop these potential.

\section{References}

Barrena R, Casals E, Colón J, Font X, Sánchez A, Puntes V (2009). Evaluation of the ecotoxicity of model nanoparticles. Chemosphere 75:850-857.

Bassiri M, Wilson AM, Crami B (1988). Dehydration effects on seedling development of four range species. J Range Manag 41(5):383-386

Carmen IU, Chithra P, Huang Q, Takhistov P, Liu S, Kokini JL (2003). Nanotechnology: a new frontier in food science. Food Technol 57:24-29.

Casals E, Vazquez-Campos S, Bastus NG, Puntes V (2008). Distribution and potential toxicity of engineered inorganic nanoparticles and carbon nanostructures in biological systems. Trends in Analytical Chem 27:672-679.

Chen F, Bradford KJ (2000). Expression of an expansion is associated with endosperm weakening during tomato seed ger- mination. Plant Physiol 12(4):1265-1274.

Chen K, Arora R (2012). Priming memory invokes seed stresstolerance. Environ and Exp Bot (in press).

Clément L, Hurel C, Marmier N (2012). Toxicity of $\mathrm{TiO}_{2}$ nanoparticles to cladocerans, algae, rotifers and plants - Effects of size and crystalline structure. Chemosphere (in press).

Daood HG, Biacs P, Fehér M, Hajdu F, Pais I (1998). Effect of titanium on the activity of lipoxygenase. J Plant Nutr 11:505-516.

Feizi H, Rezvani Moghaddam P, Shahtahmassebi N, Fotovat A (2012). Impact of bulk and nanosized titanium dioxide $\left(\mathrm{TiO}_{2}\right)$ on wheat seed germination and seedling growth. Biol Trace Elem Res 146:101-106.

Foltete AS, Masfaraud JF, Bigorgne E, Nahmani J, Chaurand P, Botta C, Labille J, Rose J, Férard JF, Cotelle S (2011). Environmental impact of sunscreen nanomaterials: Ecotoxicity and genotoxicity of altered $\mathrm{TiO}_{2}$ nanocomposites on Vicia faba. Environ Pollution 159:2515-2522.

Ghosh M, Bandyopadhyay M, Mukherjee A (2010). Genotoxicity of titanium dioxide $\mathrm{TiO}_{2}$ nanoparticles at two trophic levels: plant and human lymphocytes. Chemosphere 81:1253-1262.

Haghighi M, Heidarian S, Teixeira da Silva JA (2012). The effect of titanium amendment in $\mathrm{N}$-withholding nutrient solution on physiological and photosynthesis attributes and micronutrient uptake of tomato. Biol Trace Elem Res DOI 10.1007/s12011-012-9481-y

Hartmann HT, Kester DE, Davies, FT (1990). Plant propagation: principles and practices. Prentice Hall, Englewood Cliffs, New Jersey, 647 p.

ISTA (2009). ISTA rules. International Seed Testing Association. Zurich, Switzerland.

Khodakovskaya M, Dervishi E, Mahmood M, Xu Y, Li Z, Watanabe F (2009). Carbon nanotubes are able to penetrate plant seed coat and dramatically affect seed germination and plant growth. ACS Nano 3:3221-3227.

Khot LR, Sankaran S, Mari Maja J, Ehsani R, Schuster EW (2012). Applications of nanomaterials in agricultural production and crop protection: A review. Crop Protection 35:64-70.

Kiss F, Feher GD, Balough M, Szabolcsi A, Pais L (1985). The effect of titanium and gallium on photosynthetic rate of algae. J Plant Nutr 8:825-831.

Klancnik K, Drobne D, Valan, J, DolencKoce J (2011). Use of a modified Allium test with nano $\mathrm{TiO}_{2}$. Ecotoxi Environ Safety 74:85-92.

Kužel S, Hruby M, Cígler P, Tlustoš P, Van PN (2003). Mechanism of physiological effects of titanium leaf sprays on plants grown on soil. Biol Trace Elem Res 91:179-189

Lee WM, Kwak JI, An YJ (2012). Effect of silver nanoparticles in crop plants Phaseolus radiatus and Sorghum bicolor: Media effect on phytotoxicity. Chemosphere 86:491-499.

Lei Z, Mingyu S, Xiao W, Chao L, Chunxiang Q, Liang C, Hao 
H, Xiao- qing L, Fashui H (2008). Antioxidant stress is promoted by nano-anatase in spinach chloroplasts under UV-B radiation. Biol Trace Elem Res 121:69-79.

Li F, Wu X, Tsang E, Cutler AJ (2005). Transcriptional profiling of imbibed Brassica napus seed. Genomics 86:718-730.

Lin D, Xing B (2007). Phytotoxicity of nanoparticles: inhibition of seed germination and root growth. Environ Pollution 150:243-250.

Lu CM, Zhang CY, Wu JQ, Tao MX (2002). Research of the effect of nanometer on germination and growth enhancement of Glycine max and its mechanism. Soybean Sci 21:168172.

Maguire ID (1982). Speed of germination- Aid in selection and evaluation for seedling emergence and vigor. Crop Sci 22:176-177.

Matthews S, Khajeh-Hosseini M (2007). Length of the lag period of germination and metabolic repair explain vigor differences in seed lots of maize (Zea mays). Seed Sci Technol 35:200-212.
331

Navarro E, Baun A, Behra R, Hartmann N B, Filser J, Miao A, Quigg A, Santschi PH, Sigg L (2008). Environmental behavior and ecotoxicity of engineered nanoparticles to algae, plants, and fungi. Ecotoxicology 17:372-386.

Varier A, Vari AK, Dadlani M (2010). The subcellular basis of seed priming. Current Sci 99:450-456.

Vashisth A, Nagarajan S (2010). Effect on germination and early growth characteristics in sunflower (Helianthus annuus) seeds exposed to static magnetic field. J Plant Physiol 167:149-156.

Wilson AM (1973). Response of crested wheatgrass to environment. J Range Manag 26(1):43-46.

Zheng L, Hong F, Lu S, Liu C (2005). Effect of nano-TiO on strength of naturally aged seeds and growth of spinach. Biol Trace Elem Res 105:83-91. 